\title{
Disinheriting the inheritance: universal proclaiming and local dissonance
}

\author{
Harsha Munasinghe
}

\begin{abstract}
Today, we live in a modern world, in which an economic society characterised by individualism has been transformed. The 'West', becoming the materialistic and ideological centre of this divided world, sets norms and values for the periphery. The intensive discussions on culture, heritage and identity are emerging today, but they are framed by the globalisation of world cum individualisation of society. Emphasising the market value, the modern heritage discourse turns the inherited items into commodities. The international charters and documents, styled after the Western modernism, have not resisted this either. They disconnect the heritage from its spatial as well as social context as their assessment procedures and protection approaches are fashioned according to the economic society. The national charters, mostly styled after those international documents, fail to establish the cultural continuity. The modern heritage discourse thus causes disinheritance. This paper studies the heritage discourse, with aims to emphasise the potentials of a decentralised assessment and ascription of values to lay foundations for a post-economic society.
\end{abstract}

\section{Introduction: Modern City in the Divided World}

By the fall of colonialism, the colonial powers had laid foundations to divide the world as the centre and periphery. ${ }^{1}$ They, assuming the role of the ideological and materialistic centre, banished the former colonised non-western territories to the periphery. The centre, manipulating the racked wealth, monopolised markets and new communication networks and media, has reinforced its vicious grip (King, 1990). ${ }^{2}$ The first Industrial Revolution and its brainchild Modernism played a key role in creating the centre-dependent periphery by causing an inferior complex in the minds of the post-independent society. The post Industrial Era or the Computer Age worsened this later. The Western forms of rationality, materialism and progress were exported to the periphery, so the newly created 'nationstates' in the periphery may follow the ideologies to improve their standard of life with the status of a "civilised nation' in order to attract foreign investment. ${ }^{3}$ In this era of the economic society, being attractive to foreign investment has by now become more important than continuing traditions or rebuilding a subdued nationality.

Globalisation, which is the other known term for this submerging in one value system, refers to the comprehension of world and intensification of consciousness of the world as a whole (Robertson, 1992). This hardly means global interdependence but the dependence of the periphery on the centre as this compression does not mean a diversity within a smaller space but a dominance of the hegemonic centre over the inferior periphery. ${ }^{4}$ The stream of discourses that follow modernism, defined by sticking the word 'post': post-structuralism, postmodernism or post-capitalism, have also failed to prevent the degradation of nature and culture where the new ideas were planted. They, in fact, resulted in a full-scale homogenisation.

Modernism plays a significant role in globalisation by supplying values and norms. Modern movement reached its historic prestige during the decades between the two World Wars. ${ }^{5}$ It was born in the spirit of the renunciation of the old world, a commitment to industrial society, and an enthusiasm for exploring the potentials of materials and technologies that was the main theme of the philosophical, ethical and practical discussion developed by the then generation of architects and engineers. Structural rationalism and formal repertoire of the modern designer, fed and inspired from the machine aesthetic, became the physical responses for the mass housing need as well as other social problems that the modern architects passionately believed in solving. For example, Le Corbusier believed that he had a duty to non-modern India by planning the machinelike city, Chandighar. ${ }^{6} \mathrm{He}$ considered this modern totalitarian utopia would be the ideal solution for the society in transformation. ${ }^{7}$ The 'efficient' urban spaces of modernity shaped by the 'golden rules' transformed the society according to the Western modernistic ideologies. $^{8}$

Modernity project, Habermas (1981) finds, was aimed at the rational organisation of everyday life, development of objective science, autonomous art, universal morality and law, all with no specific historical ties. Since then the distinguishing mark of the modern works has been the 'new' (ibid.). This project drastically neglected the notion of place and past as modernity dreamt of solving and discovering every aspect of human life through science, technology and rationality. ${ }^{9}$ The modern city and its built forms boldly expressed this cultural discontinuity. The project establishes "... a single correct mode of representation", notes Harvey (1989:73). The aim may have been to liberate human beings by 
decentralisation of knowledge and by reliance of scientific knowledge, but the experience of the WW II caused serious doubts in this assumption. Horkheimer and Adorno, criticises this logic behind modern rationality, and argues that it is in fact "... a logic of domination and oppression" (cited in Harvey, 1989:79). The end result was the divided world as the single correct mode was to represent the centre at the expense of the desires of the periphery.

Those who preached modernism in the new nation states emphasised the potentials of freeing the new society from its 'dark' past. ${ }^{10}$ There was no need to continue the 'backward' traditions, as it was possible to invent 'new traditions', or there was no need to protect an inefficient historic built forms or cities as it was possible to build new within a shorter time, and whenever they failed to deliver goods then they could also be disposed. In the periphery, where the traditions had been discontinued, social structure had been molested, and the society had been forced into unknown space, Western modernism provided the ultimate vision of future. ${ }^{11}$ The new life styles not only changed physical environment of the modern city but also the inspiration sources for its creation, production and occupation. The rejection of history due to the absolute faith in the future resulted in the depreciation of values attributed to the lived city. The initiators of modern designs denied and gradually led the destruction of the historic urban spaces. The cultural diversities and the social parameters of the new city were trimmed off through international styles. The result is a city matrix that attests to the ultimate modern desire to totalise the city space (Boyer, 1994), or in other words the international style.

As the modern architects staged full scale rebuilding of cities to mark the formation of the new society, ${ }^{12}$ cities lost landmarks, traditional pageants, monuments, and other characteristics unique to them, ${ }^{13}$ Mumford (1936), a Modernistic ideologist, condemned the contextoriented attempts to urban planning such as the works of Geddes, because he believed that the modern man did not deserve to live in a 'museum-city'. The attempts to tear down historic city quarters by modern designers to set up new universal rules are well recorded (Bengs, 2000). These rules coated localities with sheer ideologies, threatening their liveability. The modern designer, failing to note the essence of the city as an establishment of living, built individual boxes wrapped in green belts and then segregated urban districts by the functions. The city was without public spaces, streets or squares. The individual buildings did not correspond to the way of life, and the interrelationships between spaces did not represent the social structure or the social organisation. The schism between 'internal order and external order' turned the city into an unliveable place. ${ }^{14}$ The intermediate spaces such as verandas, balconies, etc., became barriers isolating man in society. The rational built forms of the first phases of modernism were disciplined and temporal, but the disguised post-modern forms lost even that integrity for recreating surfaces without meanings. The city, without expressing its lived cultures, became a temporary stage to be conquered or abandoned. The creation of the decomposed society and the compartmentalised city are results of the Western modernism that divided the world as Centre-west and Periphery-rest.

Globalisation of the world cum formation of the individualised consumer society has weaken the transformation that aims at bringing back diversities and specificity of culture, heritage and identity on one hand, and on the other, has given birth to the reappearance of localism, populism, fundamentalism and regionalism. Anti-modern attitudes emerged due to the recognition of notion of history, culture, and identity as place-bound, challenge Modernism for denouncing the past, context and continuity..$^{15}$ They focus on 'end of history', 'end of culture' or 'end of tradition', have given birth to concepts such as cultural diversity, place-bound carrying capacity, cultural sustainability, multiculturalism, etc. We intend to search the possible role of the cultural heritage in this discourse.

\section{Cultural Heritage in the Global-World}

As a reaction to modernity and its attempts to leave the past behind we saw the emerging discussions. on past, heritage and identity. The first Industrial Revolution depreciated the human muscle but gave birth to the significant voices on cultural heritage. In this age of machinery, techniques of reproduction was given prominence over the continuing production. The product was detached from its process of production. Benjamin (1969) notes, the object produced in the machine age had nothing to do with the domain of tradition. Modernity dictated an incomprehensible schism between us-inpresent and us-in-past, so the past became exotic. ${ }^{16}$ With industrialised reproduction establishing a veneer universal conscious over the social and cultural conscious, this exotic past became a consumer item. The modernity, spreading a cold, abstract, rational look over the surface of things of its fragmented image, failed to make any contribution to memory or a collective being, but to a series of fragmented and privatised events.

Realising the causing cultural discontinuity and losing identity as a result of Modernity, some architects found the Restoration Movement in Europe, which aimed at correcting or beautifying an imagine past rather than protecting what had been documented. ${ }^{17}$ The Society for the Protection of Ancient Buildings (SPAB) emerged in this context, challenging the Restoration Movement and emphasising the need to strengthen the arts and crafts in order to produce the lost ties with the built stock rather than correcting it. The SPAB and its patron William Morris were a driving force for pushing towards legal protection of listed buildings and emphasising the need for protecting them in their full authenticity. ${ }^{18}$ The focus of this anti-restoration was necessarily on 
individual buildings but without ignoring the human scale and liveability of the historic city. The revitalisation of city centres and adopting them to the current way of living followed this initiative. New research works on traditional styles were started, emphasising the historic forms as a material product of a specific historic condition. They aimed at deciphering those forms that were seen as inseparable from the built environment. The protection of the built heritage against to modernistic assaults took a new momentum when the European cities embarked on intense conservation to save the built heritage.

In 1830, French towns prepared the grounds for systematic protection of individual buildings. The Department of Historic Monuments that carried out a massive inventory of historic buildings (Kain, 1981:6). The old town centres become the core of interest in establishing a particular identity of a lived city. Conservation was limited to a few selected monumental buildings that were the main features of the particular townscape. This was a piecemeal protection that paid no attention to the spatial context but to the age and style of individual buildings, and as such, was a cruel victim of modernity that was expected to be defeated. The Athens Charter (1939) and the Venice Charter (1964) they both dealt with individual buildings. In late 1960s, spatial contexts and their meanings within the contemporary society became significant. Giovannoni (1971) sharpened this attitude by promoting the protection of minor architecture along with monuments. Urban conservation eventually became a major tool in restructuring the city spaces with the aim of transferring the historic image of the city from the private to public realm (Boyer, 1994:407). The widened concept of heritage and broadening value community encouraged the European city to develop new approaches to design and planning the living city.

Expansion of the heritage discourse to regain a lost identity, meanings or to build a national identity turned out be a fairly significant affair in the post-colonial era. ${ }^{19}$ Heritage protection was then a central issue for each culture, but today it is a duty of the international community. ${ }^{20}$ This may be viewed as a development resulted by the co-existent of cultures. The most crucial duty of the international community is to prevent this rich mosaic of culture from fragmenting. We shall look into the development of the international charters without ignoring their context of two world wars and forceful alliances between different world forces.

The At'inens Charter marks a milestone by advocating a diversified attitude to cities, in which "... the character and external aspects of the cities should be respected," and went on to protect those with, "... picturesque perspective treatments". Its principles fashioned an approach to protect the shells of buildings, and the preservation plans based on this aimed at protecting a selected past glory without reviving the interconnection between them. The protected buildings became floating objects or 'masters without frames', and as such, were not different from the modern buildings. ${ }^{21}$ The first phase of concern for the historic city was less organised localised attempts arose by some forms of attachments to the particular place.

The second phase of more organised concern is marked by the birth of the Venice Charter, which defines cultural heritage as, "... imbued with a message from the past, the historic monuments of generations of people remain to the present day as living witnesses of their age-old traditions". It aimed at recovering the pride of the destroyed historic cities. The charter pays undue attention to buildings, materials, surfaces, and to their materialistic authenticity following William Morris and Cesare Brandi, and promotes a protection that isolates heritage from its own context and its process of production. ${ }^{22}$ The Amsterdam Charter of 1975 and the Washington Charter of 1986 are two attempts to bridge the gaps created by the Venice Charter. The former renders a protection to the 'European Architectural Heritage', attesting to the need for integrating the region in a cohesive unit to form a regional identity in order to manage the continuously diversifying urban culture. ${ }^{23}$ The Washington charter of 1984 has been successful in designing a protection for the tangible elements of the historic city as a whole, but its failure to take living culture and evolving life in to account as an integral part of the built heritage creates meaningless urban spaces. The charter, with its objectives to preserve "... historic character of the town or urban area and all those materials and spiritual elements that express this character", has prepared the grounds for the conservation of the urban tissues. ${ }^{24}$.

All charters and the World Heritage Convention of 1972, representing the Western concepts and philosophies, pay more attention to the continuity of the material substance. The principles and objectives of the charters discus only the tangible components of the heritage, reflecting the piecemeal approach cemented by modernism. Their failure to note the precedence given to the process of production of artefacts by some cultures over the end product eventually disturbs the established value system in some contexts. The charters framed by the Western thoughts generally emphasise intrinsic values such as age and style over inherent values such as cultural significance. The materialistic authenticity that is urged to preserve by these charters is a mere myth in many cultures. ${ }^{25}$ As such, this Western-oriented assessment fail to find the cultural diversity reflected in the World Heritage sites. Warren (1980:11) notes that authenticity of an ancient artefact once destroyed can never be recreated: "It may be reproduced, but the reproduction is merely a reproduction". The World Heritage Convention has also emphasised this point, yet since the convention uses the authenticity test as the prime scale to assess the universal significance of the heritage sites, authenticating is going on. ${ }^{26}$ As we know authenticating result in deforming of an artefact rather than protecting 
it. ${ }^{27}$ The dominance of the centre in heritage discourse has been criticised by the scholars in the centre, thus calling for redefining of the concepts locally in order to protect the heritage with its own specificity. ${ }^{28}$

The second Industrial Revolution of the latter decades of the $20^{\text {th }}$ century accelerated the appearance of new technology and their spreading through out the world in an incomprehensible speed. The transformation of the process of creating the world society during this era reinforced the dominance of the centre over the periphery. In this era, also is known as Post-Industrial era, the information processors replace the human cognitive power dramatically. So we see a change in the value systems and their evolution pattern, affecting our notion of being. Urban space, cultural heritage and ways of life are being homogenised in a global scale. Memory walks, museums and art galleries housed in the restored city cover the lived city with a 'cultural blanket' in order to be temporarily occupied.

Desires to return to past or traditions mostly occur in moments of crises. ${ }^{29}$ The current cultural charade in the lived city is no better than the holy phrase of postmodernism, 'the Presence of the Past', which was more a cloning of the past or its fractions. This new-ism has failed "... to draw attention to the contextual and linear relations of new architectural forms as they relate to past urban images, rather than stressing the differences, the rupture between then and now, here and there, and the memory of things and events that have never and can reoccur in the present" (Boyer, 1994). Transportation of surface-pasts for fantasy has mystified the glorified images in a fragmented and imaginary form without responding to the key issues of that construct the image of time or of place. Postmodernism completes the task embarked by modernism, strengthening the dominance of the centre by exploiting our favouring for the romantic past and signifying a full-scale homogeneity, and as such, denying the periphery its own inheritance.

We see an increasing discussion on past and its conservation, or a widening concern over the historic heritage along with the globalisation. Yet, it has not so far been able to recompose the society by transforming a common consensus or adopting a place-bound value system, but has become a victim of the continuing dominance of context-less modernism. Appleyard (1979:21) finds that this discussion has both "... healthy and neurotic aspects". The conservation, concerned with its own ideology, ethics, methods of repair and reuse has raised much controversy. Mac Cannel writes the dilemma as, “... the final victory of modernity, is not the disappearance of the non-modern world, but its artificial preservation and reconstruction in the modern society" (cited in Appleyard, 1979:10).

\section{Heritage City and the Nation State}

The anthropological approach to cultural heritage leads us to consider the heritage city as a social ensemble needed to be protected for the humanity. For example, the use of the historic city in the construction of a national identity, as a place-bound activity aimed at strengthening the man, society and environment relationship, did serve the heritage rightly. As Graham et al (2000) note the rise of nation state was closely connected to Romantic sentiments of the mysticism of place. The nation state created during modernism that preached the liberation from past and place, "attempted to fix space through the creation of rigidly territorial nation-states, promulgating ideologies, which attempted to subsume differences through representations of homogeneity" (Graham et al, 55). The myth of homogeneity only resulted in genocide and atrocity as those who did not fit the desired image were eradicated. ${ }^{30}$ The modern nation state was established within the norms provided by the former master, and its national identity was thus external oriented in order to attract trespassing economic benefits. This modern national identity, with clear beginnings and endings, was an object bounded in time and space (Handler, 1994), and as such a consumer item. Some selected pasts of a historic city are over-used as the spinal cord of the national heritage, inserting them into a system of exchange by abstracting its elements from the values assigned by the local societies. ${ }^{31}$

As a whole, we witnessed to a process of heritagemaking, in which the lived city was turned into a commodity for the consumer society in the centre thus disinheriting the societies living in the periphery. This restructuring of the past leads to historicism and nostalgia criticises Hewison (1987). He notes the increasing trend in England to promote past as a new kind of nostalgia that, "... has become an economic enterprise, as the commercial interests of manufacturers and advertising have recognised" (ibid: 29). This Heritage Industry, an offspring of modernism, exploits economic potentials of the artefacts, and emphasises the economic gains as the reason for the conservation of the historic city (Munasinghe, 1988 \& 2001). The enforced market value, promotes endless types of museums, art galleries, handicraft and design studios and shops, etc., along with fast-food outlets and various types of restaurants and amusement functions. Most importantly, these functions are to serve the economic society of the centre, disinheriting the locals who are unable to compete with the strong centre. The modern-conserved city fashioned to attract tourists and multinational footloose enterprises deforms the transformed city images and the evolved investment patterns. Bayliss (1994) warns that the over emphasis on a few selected economic activities in the so-called heritage-city also cause an uneven growth of the service sector at the cost of the production sector. Tourism being a fragile economic affair, this will have detrimental impact upon the liveability of the historic city. 
The reproduction of a past contradicts the own argument for heritage protection on continuity since it perceives historic urban form as an object rather than a process, and it presupposes a petrifying of those images rather than strengthening their continuos making through using. The living environment will not necessarily be improved through such preservation, which may halt deliberate destruction for the time being. In most efforts some leftover remnants of our cities are kept as a visual imagery of a past to pictorialise the urban space. The pictorialisation, by presenting a purposely-framed urban reality as arts of commercial functions, has failed to sustain our resistance to the hegemonic tendencies of global technology and multinational capitalism (Boyer, 1994). Historic preservation was not only pictorial additions inserted into the centre of the modern space but one of the most dreadful and real developments of the contemporary world being the example of commodification of cultural heritage (Root, 1996). The ideological centre is responsible for commodification of the historic city and causing the degradation of its liveability.

The adjustment of reality to the masses and of the masses to reality is a process of new values in which to ask for the 'authentic' character of work of arts makes no sense as its contemporary function is based on practice-politics and is received on the exhibition values (Benjamin, 1969). The most prevalent character of the modern culture is reproduction that has considerable effects on the city space. Lefebvre (1994) taught that the city space is a product, marked, measured, marketed and transacted like any capitalists tool, the efficiency and functionality of its performances are studied and perfected, as a commodity its representation form is restyled and reformed. Urban conservation is plunging in to nothing more than improving the market value of the urban space. The declared city has certainly raised its market values for the benefit of the materialistic centre. The locals in the periphery have no means to compete the centre to maintain the access to this high-priced urban space. The few who have the means are mere agents of the centre that perfects and reshapes the city as a magnet for investments. The disinheritance of the heritage city to its evolved societies is therefore unavoidable.

In order to convert heritage into a commodity, the historic city is signified as an artefact by geographically delimiting and architecturally delineating. The city is decomposed as a result thus alarming the end of an urban culture rather than reinforcing its continuity. The typified heritage city is presented to the visitors through memory walks, picture post card views, etc., programmed to satisfy the centre. Boyer (1994:29) notes, "We are compelled to create new memory walks through the city, new maps that helps us resist and subvert the all- too- programmed and enveloping messages of our consumer culture". These memory walks have no memories of their own, but a 'simulacrum'. ${ }^{32}$ The presentation norms that pay less attention of the unique urban culture cause the loss of legibility, and as such, disinheritance to the locals.

In the city, its continuity as a place of living, its capacity to hold a living society, and to enable comfortable dwelling are more important than this marketability. Since the city becomes a heritage by being a setting of a continuing culture, and since the built fabric has no meaning without a continuing life, the discontinuity caused by the modern heritage attitudes is rather detrimental. We conservationists satisfy the demands of the modern economic society, thus recreating heritage cities rather than conserving them and as such, sacrificing the common value system and the ownership patterns that have developed over centuries. We remain today unable to escape the ambivalent tensions between new and traditional, and fail to look at the concepts of value, conservation, and heritage within the own diversities. The universally defined concepts mean a centre dominated protection that eventually disinherits the periphery of its own inheritance. We hardly discuss the value of cultural heritage as a resistance to the global cognitive, material, cultural invasion, but emphasise the need to protect cultural heritage for its universal values and for its marketability in the global market.

\section{Reclaiming the World Heritage City}

The attitude of 'being global' dominates the World Heritage List that assesses and presents a heritage based on an objective materialistic authenticity. ${ }^{33}$ This test is based on design, materials, workmanship, and the (physical) setting, and its promotion as a global tool undermine the possible cultural determinations of heritage. The specificity loaded with the concept by focusing onto its materialistic objectivity has roots in the centre-dominated global agenda. Universal understanding, as a concept, does not acknowledge cultural diversity of the concept of authenticity. The Guidelines to Declare and Manage the World Heritage Sites pay no attention to the local definitions but rigidly proposes a 'Euro-centric' attitude. Lowenthal (1994) has proposed to include the particular way of appreciating a heritage by its living culture in ascribing the sites on the World Heritage List. He emphasised that the concept of heritage as well as its authenticity are highly contextual. The authenticity test seems to favour the centre and a selected minority thus disinheriting the 'weak' locals. The World Heritage list, choosing 'heritage of object' over 'heritage of idea' (Faulkner, 1978), seems to represent the continuity of our preferences for materials substances. Inscribing on the list, as such, is becoming a classification of cities into a global framed system, which promotes the market values within the centre.

A recent report presented to the World Heritage Centre argues that, "... the designation of world cultural heritage is biased to Europe, historic towns, religious buildings and Christianity, against prehistory, twentieth century, 
vernacular artefacts and living cultural traditions" (cited in Graham et al., 2000:242). Ignorance of non-material cultures, living traditions, and the intangible aspects undermine the aims of protecting a cultural heritage for the humanity. Today, this assessment of World Heritage sites has been decentralised, but the regional experts commissioned for assessing still follow the norms set by the centre, not to mention that the experts are chosen for displaying their obedience to the centre. The politicians, seeking fame and fortune by getting their city inscribed on the list, make sure that these assessors are happy with the ability of the sites to perform for the tune of the centre rather than looking into the current needs of the community. ${ }^{34}$ In the periphery, the universal declaring is justified with use of potential market values, international funding and universal recognition. The new nation states, especially in the former Communist block, use the opportunity of the universal declaring to rebuild a new image that glimpses a liberation from their stagnant recent past to promote foreign investment. The new policies and urban management tools in the three Baltic capitals are the most instructive examples for this trend fuelled in their World Heritage cities. These cities are promoted as the last bastion of the western culture thus emphasising their origins and pre-Soviet outlooks. The locals are forced to forget the social injustice and deteriorating living states in their setting in order to maintain the universal values of the re-found old image.

World Heritage List, instead of encompassing a representation of values in their particular uniqueness, simply typifies cities according to the Western values. The conservation pundits, living physically or nonphysically in the centre, speak of one universal language, completing the gig-saw puzzle of the global-space. The notion of professionalism that condemns the public as mere novices may have originated during the industrial colonialism and raised by modernism, but it is the World Heritage List that signifies the full blooming of this professional/ novice division and high culture/ low culture debate. The universal declaring turns the historic city into a global object; declared for all- proclaimed by none. Its values are to be understood by those visiting experts rather than by the locals. The evaporation of life and increasing crime rates attest to the disinheritance caused by the universal declaring.

Conservation of urban heritage has been broadened over the last four decades, especially in architectural and planning forums. The emphasis on developing regional and local conservation policies has been growing too. The conservationists are trained in a more regionoriented system. The periphery that has not maintained a documentation and continuity of traditions in a substantial way as a result of the colonial dominance or the systematic destruction in the hands of the centre, comes into terms with what their versatile heritage has become today. The citizens are being brought into the decision making process too. What is missing is decentralising the culture and culture-related terminology, so the world becomes more versatile. Once culture is described as the man's reaction to nature where he created a living pattern, the lost ties could be easily restored. It is the duty of each individual and their sub-cultural groups to look into their selves and examined not only the documented past moments but also their circumstances. By challenging the precedence given to the economic values, we may compose the post-economic society by counterattacking the main characteristic of the economic society, the tyranny of individualism. Appreciating not only what we have inherited and practised but also what others have inherited and practised, there is still a possibility to reinstate the society within a diversified cultural system. Then, protecting cultural heritage through continuing their production processes, we need to shift our emphasis on the culture as a process that binds us together rather than a product of some unknown past. The aims of protection of the cultural heritage shall also be shifted from the economic gains to the quality of life. Here we need a more responsive selection process to identify, assess and ascribe values of cultural heritage.

What is more important in the city is enabling man to regain his cultural identity to liberate himself from the dominating centre. Heritage enhances this endeavour significantly by placing him in his society and environment. A protected urban setting could very well be the charging field for cultural identities thus allowing him to be rooted and encouraging him to formulate a stable society. By interpreting, assessing and protecting the World Heritage city within the local identity and locally defined authenticity, we should emphasise the local ownership as axiomatic in order to support this endeavour. This regained ownership of the place and the protected urban quality of the historic city will promote continuous living thus keeping the city a universally significant artefact for what it has become. Concept of heritage is an assertion of an ownership. The assertion of ownership by declaring the World Heritage should not cause disinheritance in any context. The potentials of the World Heritage list to enhance the value community should be positively used to enable the liveability of the World Heritage city.

Tunbridge and Ashworth (1995) note that by underlining the distinction between identity and interpretation, inevitability of disinheritance must be modified. They note that in a plural society, in which different groups have no obvious generalised dependencies, the assertion of ownership by one group does not necessarily cause disinheritance in others if "... the mutual indifferences, tolerant acceptance as of necessity, and mutuality of esteem that leads to mutual association and participation" (Tunbridge and Ashworth, 1995), are respected. In other words, the failure to respect the cultural diversity of the periphery causes disinheritance. We shall remember that heritage is a social construction, and its protection is a process of ascribing values and assigning roles with declared 
objects. This means these ascribed values are more significant that those objects.

\section{Remarks: Decentralising Heritage Protection}

Today, heritage is regarded as an asset and a resource, an asset with which we ascribe values and a resource that could be used to improve the living conditions and social welfare. It shall acquire the central role of development. As a result of this new awareness, the heritage discourse is taking a sharp turn from historic to futuristic with more emphasis being placed on its relationship to the place. With the final report of the UN World Commission on Culture and Development entitled, Our Cultural Diversity emphasising the need to focus on the specificity in each culture and bring their uniqueness to the centre of discussion, we owe to the new concept multiculturalism. As the report suggests, we could frame a culturally sustainable development by respecting diversities and specificity of each cultural system. In the Nordic countries, research on the identity of historic wooden towns and its significance to the urban culture has increased. There, the researchers tend to read the historic urban parts as material products of specific historical conditions, and are eager to investigate for the continuity of those traditions through protection of the sites. The subject of study for this new trend was more to decipher historic features that are seen as inseparable and constitutive parts of the city space. Less-diversified Nordic city seems to have eased the question for the complex issue faced by city in the periphery, especially its withstanding the current process of globalisation through creating a new awareness of place-bound tools to assess, appreciate and protect the cultural heritage. The economic strength of the Nordic society is able to pay for the values added by protection. The resource value of heritage would provide answers without falling back into its elitist outlook.

Heritage is a spatial phenomenon, characterised by location, distribution and scale (Graham et al., 2000:256). It is undoubtedly socially constructed as these characters, interpreted by diverse subcultures differently, have a social bearing. The potentials of heritage as an economic/ political instrument tie it down further with the place.$^{35}$ In this era of hybrid societies in the 'compressed' world, the importance of place is becoming more significant. Having noted this close connection between heritage and place, heritage conservation may construct a cultural identity, a placebound determinant of the meaning of belonging.

We shall note that the culture is always in the making and its accumulation process shall be paid attention in interpreting heritage rather than the images of an exotic homogeneous culture- a marketable commodity. ${ }^{36}$ The ever-diversifying cultural mosaic shall not leave the roots behind nor it shall exclude some sub-societies in the name of authenticity. By overcoming the materialistic construction or non-materialistic destruction of cultural heritage, the evolving heritage proclaiming patterns shall be respected. We note the need to emphasise the process of production of heritage, physically or non-physically, as a better alternative to petrifying those cult-items. By responding to the call of the last report resulted by the World Commission on Culture and Development to respect the cultural diversity of place ${ }^{37}$ we emphasise the close links between heritage, place and identity. Focusing on to locally-evolved interpretations thus assigning culture-desired representational roles with the cultural heritage, the uniqueness of the place could be resorted. We shall bring intangible components of heritage, especially the production and proclaiming of heritage-items, to the forefront by reviving traditions such as carpentry, handicrafts, etc. These traditions of production or the ways of life that transform built space into a heritage contribute to the uniqueness we find in our inheritance.

It is worthwhile to look at the value of heritage and, to redefine conservation as a cultural process that assesses prevailing values, ascribes new values, and interprets values, diversifying a local discourse. Further it is not saving a built space but investing in that space for a present and for a future. It is not returning to a past but building a future based on that past. This conservation, without aiming the marketing of a culture, could attract investments for its cultural values and productivity by reinstating the authentic investment patterns and living styles in the urban space. By proclaiming the city a heritage for the life lived, conservation could reinforce the culture-desired space-production. The urbanity, the unique urban essence of the space which makes the city legible should be given priority over its individual elements; buildings, streets, activities, concepts, etc., in framing the conservation aims. A heritage-city protected on these lines would challenge the illusionary powers of the centre. The inherited urban landscape could become a cultural asset, and its conservation could become an enabling process to boost their living.

The day we look at the complex social and cultural values of cultural heritage within the context and evolve heritage protection within these demands of the local society, we shall be able to disjoint our city from the global systems. The concept of multiculturalism and the possible options of social integration as well as the potentials of inter-society and intra-society communication seem to show some light in keeping our cultural identities, or their presentable forms, thus laying foundations to the idealistic 'post-economic' society. This new society, not dependent on economic achievements of individuals, may construct new institutions, ideas and life forms that will bring the public interests and democratic decision making processes, but place-bound. Heritage protection, once conceived as a local effort and once interpreted in local means, may lay the foundations for this. 
By following its usual way of shedding old and acquiring new values along with the evolution of the community, the heritage city could be protected as a culturally diversified living being. Its on-going space interpretation as well as architectural and morphological assembling should be protected for contributing to city's liveability. The local ownership of the heritage-city should be underlined as an axiom, but its protection shall not burden city's social or economic progress. Again, the idea of cultural diversity seems to provide the answer to find new owners for old spaces as well as new activities for old containers yet without ridiculing the old or the new. By confirming the right of access to the heritage city, right to own the urban space and right to enjoy their inheritance within their means, the locals could be promoted to share the city space with new users to evolve the new society that we term as the post-economic society.

\section{References}

Arumapperuma, Nalini and Mandawela, P.B., (1995). "Urban Revitalisation and Heritage in Galle City", The Final Report sumbmitted to the participation course of Integrated Urban Revitalisation and Heritage at the Institute of Housing and Urban Development Studies, The Netherlands.

Appleyard, D., (ed.), (1979). The Conservation of European Cities, Cambridge: MIT Press.

Bauman, Z., (2000). Liquid Modernity, Cambridge: Polity Press.

Bayliss, B., (1994). "Achieving Economic Benefits," in, Historic Towns and Sustainable Tourism: The protection and Promotion of the World's Heritage, ICOMOS UK Conference Papers, ICOMOS (UK): Bath.

Bengs, C., (2000). From Conservation to Convelopment: Nordic Countries, in Built Environment 26(1): 13-20.

Benjamin, W., (1969). Illuminations, (translated by Harry Zohn), New York: Schoken Books.

Boyer, M.C., (1994). The City of Collective Memory, Cambridge: The MIT Press.

Broadbent, G., (1990). Emerging Concepts of Urban Space Design London: Von Nostrad Reinhold.

Davidavicius, A., (1998). "Citizens versus Architects," Archiforma 1: 38-40.

Faulkner, P.A., (1978). "A Philosophy for the Preservation of our Historic Heritage," Journal of the Royal Society of Arts, $126(5,264)$ : 452480.

Furguson, A., (1973). The Sack of Bath. A Record and Indictment, Salisbury: Crompton Russell Ltd.

Giovannoni, (1971). "Italian Norms for the Restoration of Monuments", Unpublished Paper, ICCROM Archives.
Graham, B., Ashworth, G. J. and Tunbridge, J.E., (2000). A Geography of Heritage: Power, Culture and Economy, London: Arnold.

Habermas, J., (1981). "Modernity versus Postmodernity," New German Critique22: 3-15.

Hall, S., (ed.), (1997). Representation: Cultural Representations and Cultural Practices., London: Sage/ Open University.

Handler, R., (1994). "Is Identity a Useful Crosscultural Concept," in, Gillis, J.R. (ed.) Commemorations,: The Politics of Natural Identity, Priceton, NJ: Princeton University Press.

Harvey, D., (1989). The Condition of Postmodernity. Cambridge: Blackwell.

Harvey, D., (2000). Spaces of Hope, Edinburg: Edinburg University Press.

Heidegger, M., (1958). The Question of Being, New York: Twayne Publishers.

Hewison, R., (1987). The Heritage Industry, London: Methuen.

Ito, Nabu (1995). "Authenticity Inherent in Asia and Japan," in, Larson, K.E., (ed.), Nara Conference on Authenticity, Tokyo: Agency for Cultural Affairs.

Jameson, F., (199l). Postmodernism or the Cultural Logic of Late Capitalism, London: Verso.

Kain, R., (1981). Planning for Conservation, London: Mansell.

King, A.D., (1990). Urban, Colonialism and the World Economy: Cultural and Urban Foundations of the World Urban Systems, London:Routledge.

Lefebvre, H., (1991). The Production of Space, Oxford: Blackwell.

Lowenthal, D., (1985). The Past is a Foreign Country, Cambridge: Cambridge University Press.

Lowenthal, D., (1994). "Criteria for Authenticity," in, Larson, K.E. and Marstein, N., (eds.), Conference on Authenticity in Relation to the World Heritage Convention: Workshop Proceedings., Oslo: Tapir Forlag.

Lowenthal, D., (1996). The Heritage Crusade and the Spoils of History, Cambridge: Cambridge University Press.

Lynch, K., (1987). The Good City Form, Cambridge (Mass.) : MIT Press.

Miller, D. et al. (eds.), (1989). Domination and Resistance, London: Unwin Hyman.

Mumford, L., (1936). The Culture of Cities, New York: Harcourt Brace.

Munasinghe, H., (1992). Transformation of Colonial Urban Space, Helsinki: Helsinki University of Technology.

Munasinghe, H., (1998). Urban Conservation and City Life, Oulu: University of Oulu Press.

Munasinghe, H., (2001). 'Development through Conservation', in Yhteiskuntasuunnittelu 2001:4. 
Munasinghe, H., (2002). "Conserved for Living," in, Datutop 23.

Norberg-Schulz, C., (1985). The Concept of Dwelling, New York: Rizzolli.

Perera, N., (1999). Decolonising Ceylon: Colonialism, Nationalism and Politics of Space in Sri Lanka, New Delhi: Oxford University Press.

Perera, S., (2002)- "Alternate Space: Cultural Consequences of Globalisation," The Island 23/01/2002.

Philipport, P., (1976). "Historic Preservation: Philosophy, Criteria and Guidelines," in, Sharon (ed.) Preservation and Conservation: Principles and Practices, Williamsburg: Historic Preservation Foundation.

Robertson, R., (1992). Globalization: Social Theory and Global Culture, London: Sage.

Root, D., (1996). Cannibal Culture Art, Appropriation, $\&$ the Commodification of Difference, Oxford: Westview Press.

Seppänen, M., (1998). Global Scale, Local Place?: The Making of the Historic Centre of Lima into a World Heritage Site, Helsinki: Institute of Development Studies.

Silva, Roland (1974)- 'Galle Seminar Papers', Department of Archaeology, Colombo

Tunbridge, J. E. \& Ashworth, G. J., (1995). Dissonant Heritage: The Management of Past as a Resource in Conflict, John Wiley \& Sons.

Unambowe, T.P., (1990). "A glance at the statutory framework for archaeology in Sri Lanka," Ancient Ceylon 5(11).

Venturi, R., (1977). Complexity and Contradiction in Architecture, London: Architectural Press.

Warren, J., (1980). Ethics and Aesthetics in Conservation, A Paper based on Lecturers delivered at the loAAS, York (Later published in Transactions Volume 1992 of the Association for Studies in the Conservation of Historic Buildings)

World Commission on Culture and Development, (1995). Our Creative Diversity, Paris

\footnotetext{
(Footnotes)

1. Friedman (1989) and Portugal (1989) use the terms 'West' and the 'Other' to distinguish the nature of development and modernisation process. Portugal notes that West means the set of values that were created by the European part of the world without geographical significance or a precise politicaleconomic meaning; in Europe or the Europeans in the other continents such as North America and Australia, or capitalist and socialist. It more refers to a set of values shared by system, attitude to nature, industrialisation and concept of development.

${ }^{2}$. Both Munasinghe (1992) and Perera (1999) have discussed the issue of 'colonial urban development and the continuing dominance of the centre-West in the Sri Lankan context.
}

${ }^{3}$. The peripheries, where they were not followed, were condemned as fundamentalists, extremists, localists, etc. They were also not considered for investments or grants by international organisation.

4. Jameson (1991:26) notes the debate on this dominance and its chaotic developments as latecapitalism. Also refer to Perera ((2002) for a comprehensive discussion on globalisation and capitalism.

5. Modernism can be divided into three phases, as pre-modern, modern and post-modern. This paper studies only the two latter phases for their more detrimental impact on cultural heritage.

${ }^{6}$. Having failed to realise his modern utopias designed for the Western capitals such as Paris, Stockholm, the modern designer was able to exploit the inferiority prevailed in the periphery.

7. Bauman (2000:32) notes, "Modernity starts when space and time are separated from living practice and from each other and so become ready to be theorized as distinct and mutually independent categories of strategy and action",

8: Most interestingly, modern architects designed spaces and believed to trans form the society accordingly, whereas the pre-modern designer would design the space according to the prevailing social cultural aspirations.

9. Niestzesche confirmed that the aim of art should be its own self-realisation.

10. The states in the periphery such as India as well as states in the centre such as Finland fell for the traps of modernism in the creation of the nation-state image.

${ }^{11}$. Once the post-independent phase of the profession of architecture as well as the architectural education in countries like Sri Lanka, we see the transplanting of the so-called neo-colonialism through shaping values.

12. Eliel Saarinen, Alvar Aalto, and many others believed that they had a vision to modernise the lived cities and a duty to guide the rest of the citizenry towards that vision.

13. Davidavicius (1998) notes, “... the most common feature of all urban life (in Vilnius) today is schizophrenia. Old stable landmarks disappeared from the daily life of a city dweller. The city has become a changing labyrinth and we solve it like crosswords".

${ }^{14}$. We find a explicit description of these two orders in Rapoport (1977). Also refer to Munasinghe (1992) for an adoption of this model to study the transformation of the urban spaces in the Galle fort. 15. Culture could be defined as a process that transforms differences into essence. It is determined by a set of values and norms that are accepted by a group. As such, the behaviour of an individual as a member of a group signifies a culture.

${ }^{16}$. Refer Lowenthal (1986).'Past is a Foreign Country'. 17. Refer Munasinghe (1998) for an overview of the emergence of the restoration movement and its preachers such as Scott, Viollet-le-Duc. 
18. The works of William Morris, John Ruskin and the SPAB should be regarded as the first step to discuss a protection beyond the geographical restrictions. Refer The Collected Letters of William Morris (18481880).

19. Friedman (1994) argues for this renaissance in which people became aware of "doing similar things differently.'

20. The World Heritage Convention considers they as, "priceless and irreplaceable possessions, not only of each nation, but of the mankind as a whole".

${ }^{21}$. The first ever town preservation project, Williamsburg in Virginia, does not signify a cultural continuity, but a frozen historic moment in exhibition. This certainly, with aims to generate an income by touching the soft corner history, marks the beginning of the Modernistic conservation. Also refer Fergusson (1973)

22. One may easily find the dominance of the Venice Charter in the heritage conservation legislation in Sri Lanka. Also refer Unanmbowe (1990)

${ }^{23}$. Lowenthal (1991) considers that identity requires having a heritage and considering/ promoting it as unique.

${ }^{24}$. The urban wall of the city is often glorified through protection but paying no attention to what happened or is happening behind the wall. Refer Munasinghe (2002).

${ }^{25}$. Nabu Ito (1995) confessed that the word authenticity has no translation in Japanese.

${ }^{26}$. Seppänen (1998) discusses clearly how the image of the Historic City of Lima has been recreated to win the universal declaring. Also refer Munasinghe (1998) for the case of the Galle fort, where the residents are made to think that it is only the street facade that needs to be protected.

27. Philpport (1975), notes that by removing the patina, the original surface of a statue cannot be recovered but the present state of that original surface could be lost. A foreign consultant to the Department of Archaeology, interviewed by the author in early nineties, said that he wished to see the reconstruction of the 'Dutch fort' in Galle at the expense of the post-Dutch additions and alterations. Arumapperuma and Mandawela (1995) discuss a more sensible approach to revive the image of the fort, rather in line with the comments of Philpport. ${ }^{28}$. Lowenthal (1994) is among those who have voiced the Euro-centric nature of the concept of authenticity used by the World Heritage Convention to declare the 'universal significance' of cultural or natural heritage. 29. The French Revolution, world wars and recent ethnic cleansing have urged the need for protection of built heritage.

${ }^{30}$. For example, the Baltic countries often neglect the social and built fabric created during the Soviet era.

Seppänen (1998) notes ejection of people from the Historic Lima Centre in creating the Grand Colonial Arcadia.

${ }^{31}$. The World Heritage Cities in the Baltic countries attest to this form of identity-construction and marketing. Refer Munasinghe (2002).

32. Plato conceived 'simulacrum' to denote the identical copy for which there has never been an original (cited in Jameson, 1991:18).

33. The World Heritage Convention adopted by the UNESCO in 1972 at its General Conference aims at merging the protection of both cultural and natural heritage in one programme to protect their 'outstanding universal values'.

${ }^{34}$. A city is proposed to the World Heritage Convention by an intellectual minority or by politicians and not by its citizens. Those who propose also try to enlarge the heritage awareness among the public. We fell that this process should be reversed, so the public awareness leading towards proposing as that would naturally protect the site.

${ }^{35}$. Place is the location or the particular space that is identified or decoded in a particular pattern by a subculture at a particular moment.

${ }^{36}$. The destruction of the additions in Communist era is witnessed in the Baltic countries and many other so-called Eastern and Central European cities. This purification of the pre-communist image also expels diver sub-societies.

${ }^{37}$. The globally-defined sustainable development leans towards the protection of nature and natural resources, considering nature as an objective irrespective of the culture which conceives it. 